\title{
Expression of epithelial sodium channel (ENaC) and CFTR in the human epidermis and epidermal appendages
}

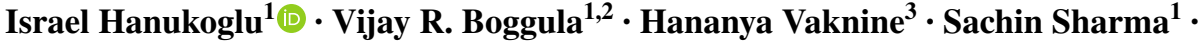 \\ Thomas Kleyman $^{4,5,6} \cdot$ Aaron Hanukoglu ${ }^{2,7}$ (i)
}

Accepted: 23 December 2016 / Published online: 27 January 2017

(C) Springer-Verlag Berlin Heidelberg 2017

\begin{abstract}
A major function of the skin is the regulation of body temperature by sweat secretions. Sweat glands secrete water and salt, especially $\mathrm{NaCl}$. Excreted water evaporates, cooling the skin surface, and $\mathrm{Na}^{+}$ions are reabsorbed by the epithelial sodium channels $(\mathrm{ENaC})$. Mutations in $\mathrm{ENaC}$ subunit genes lead to a severe multi-system (systemic) form of pseudohypoaldosteronism (PHA) type I, characterized by salt loss from aldosterone target organs, including sweat glands in the skin. In this study, we mapped the sites of localization of $\mathrm{ENaC}$ in the human skin by confocal microscopy using polyclonal antibodies generated against human $\alpha \mathrm{ENaC}$. Our results reveal that $\mathrm{ENaC}$ is expressed strongly in all epidermal layers except stratum corneum, and also in the sebaceous glands, eccrine glands, arrector pili smooth muscle cells, and intra-dermal adipocytes. In smooth muscle cells and adipocytes, ENaC is co-localized with F-actin. No expression of $\mathrm{ENaC}$ was detected in the
\end{abstract}

Israel Hanukoglu

mbiochem@gmail.com

1 Laboratory of Cell Biology, Ariel University, Ariel 40700, Israel

2 Sackler Faculty of Medicine, Tel-Aviv University, Tel Aviv, Israel

3 Division of Pathology, E. Wolfson Medical Center, Holon, Israel

4 Department of Medicine, University of Pittsburgh, Pittsburgh, PA, USA

5 Department of Cell Biology, University of Pittsburgh, Pittsburgh, PA, USA

6 Department of Pharmacology and Chemical Biology, University of Pittsburgh, Pittsburgh, PA, USA

7 Division of Pediatric Endocrinology, E. Wolfson Medical Center, Holon, Israel dermis. CFTR is strongly expressed in sebaceous glands. In epidermal appendages noted, except the eccrine sweat glands, $\mathrm{ENaC}$ is mainly located in the cytoplasm. In the eccrine glands and ducts, ENaC and CFTR are located on the apical side of the membrane. This localization of $\mathrm{ENaC}$ is compatible with ENaC's role in salt reabsorption. PHA patients may develop folliculitis, miliaria rubra, and atopic dermatitis-like skin lesions, due to sweat gland duct occlusion and inflammation of eccrine glands as a result of salt accumulation.

Keywords Actin - Eccrine gland · Epidermis . Keratinocytes · Pseudohypoaldosteronism · Reninangiotensin-aldosterone system · Smooth muscle cells . Sweat glands
Abbreviations
CF Cystic fibrosis
CFTR Cystic fibrosis transmembrane conductance regulator
$\mathrm{ENaC}$ Epithelial sodium channel
ECF Extracellular fluid
PHA Pseudohypoaldosteronism
PRA Plasma renin activity
TM Transmembrane

\section{Introduction}

In mammals, skin is a complex organ wherein different anatomic components, such as the epidermis, dermis, hair follicles, and sweat glands, and cell types such as keratinocytes, melanocytes, and adipocytes fulfill diverse specialized functions. One of the major functions of the skin is the regulation of body temperature by sweating. In this 
process, sweat glands secrete water and ions, especially $\mathrm{Na}^{+}$and $\mathrm{Cl}^{-}$, electrolytes that are present at high concentrations in the extracellular fluid (ECF) (Sato et al. 1989; Shibasaki and Crandall 2010). Water excreted in sweat evaporates, cooling the skin surface, and $\mathrm{Na}^{+}$is reabsorbed by the epithelial sodium channels $(\mathrm{ENaC})$.

$\mathrm{ENaC}$ is composed of three homologous subunits that are expressed mainly in high resistance epithelia (Hanukoglu 2017; Hanukoglu and Hanukoglu 2016). The main regulator of $\mathrm{ENaC}$ expression is the renin-angiotensin-aldosterone system (Rossier et al. 2015). The aldosterone binding mineralocorticoid receptor is expressed in the human skin, specifically in keratinocytes, sweat, and sebaceous glands, and fulfills important roles in skin biology (Kenouch et al. 1994; Farman et al. 2010). Already in 1970, Collins et al. showed that injection of aldosterone decreases sweat $\mathrm{Na}^{+}$ levels (Collins et al. 1970) presumably by stimulating $\mathrm{Na}^{+}$ reabsorption.

In 1996, we reported that the severe multi-system form of pseudohypoaldosteronism (PHA) type I (a syndrome of aldosterone unresponsiveness) results from loss-of-function mutations in genes that code for ENaC subunits (Strautnieks et al. 1996; Chang et al. 1996). In our first description of the multi-system PHA, we had reported that these patients lose salt from aldosterone target organs, including sweat glands in the skin (Hanukoglu 1991). Salt loss from the sweat glands may be especially severe in hot ambient temperatures, and together with recurrent lower respiratory tract, infections contribute to the severity of the disease mimicking aspects of cystic fibrosis phenotype (Hanukoglu et al. 1994). In cystic fibrosis patients who lack functional CFTR (cystic fibrosis transmembrane conductance regulator) chloride channels, absorption of salt is impeded despite the fact that $\mathrm{ENaC}$ is functional. In sweat glands, the dysfunction of CFTR creates conditions under which $\mathrm{ENaC}$ function is inhibited. Consequently, salt that is excreted with sweat is not reabsorbed by $\mathrm{ENaC}$ and leads to salt loss via the sweat (Reddy et al. 1999).

In a series of elegant gene-deletion studies, Hummler et al. demonstrated that besides ENaC's function in salt reabsorption in the skin, $\mathrm{ENaC}$ also has an essential role in epidermal differentiation, epidermal permeability barrier function, and epidermal cell migration (Mauro et al. 2002; Frateschi et al. 2010; Yang et al. 2013). A recent study provided evidence that $\mathrm{ENaC}$ plays a major role in the regulation of the hydration status in skin wounds and development of fibrosis (Xu et al. 2015a).

Previous studies provided evidence for the expression of the $\alpha, \beta, \gamma$, and $\delta$ subunits of $\mathrm{ENaC}$ in the epidermis (Duc et al. 1994; Roudier-Pujol et al. 1996; Brouard et al. 1999; Oda et al. 1999; Yamamura et al. 2008a). However, much of the data in these studies are about mRNA expression rather than protein localization, and the studies that have examined histochemical staining are generally of low resolution with, in some cases, doubtful identification of cells.

The major objective of the present study was to map by confocal microscopy the sites of expression of $\mathrm{ENaC}$ in the human skin and epidermal appendages, including hair follicles, sebaceous glands, eccrine sweat glands, smooth muscle cells of pili, and intra-dermal adipocytes (Fig. 1). For this purpose, we used the polyclonal antibodies generated against the extracellular domain of human $\alpha \mathrm{ENaC}$ that provided strong immunofluorescence signals (Enuka et al. 2012). In addition, we also compared expression of $\mathrm{ENaC}$ with CFTR. Our results documented here reveal that ENaC is expressed strongly in the epidermis, sebaceous glands, eccrine glands, smooth muscle cells, and intra-dermal adipocytes in the skin but hardly shows any expression in the dermis. We further documented major differences in the intracellular localization of $\mathrm{ENaC}$ in the epidermis and epidermal appendages as compared to other epithelial cells in the uterus, reproductive tract, and respiratory tract that we had examined previously (Enuka et al. 2012).

\section{Materials and methods}

\section{Antibodies}

Rabbit anti- $\alpha$-ENaC antisera against the extracellular domain of human $\alpha$-ENaC were generated in our lab (Enuka et al. 2012). Antibody against the C-terminus of

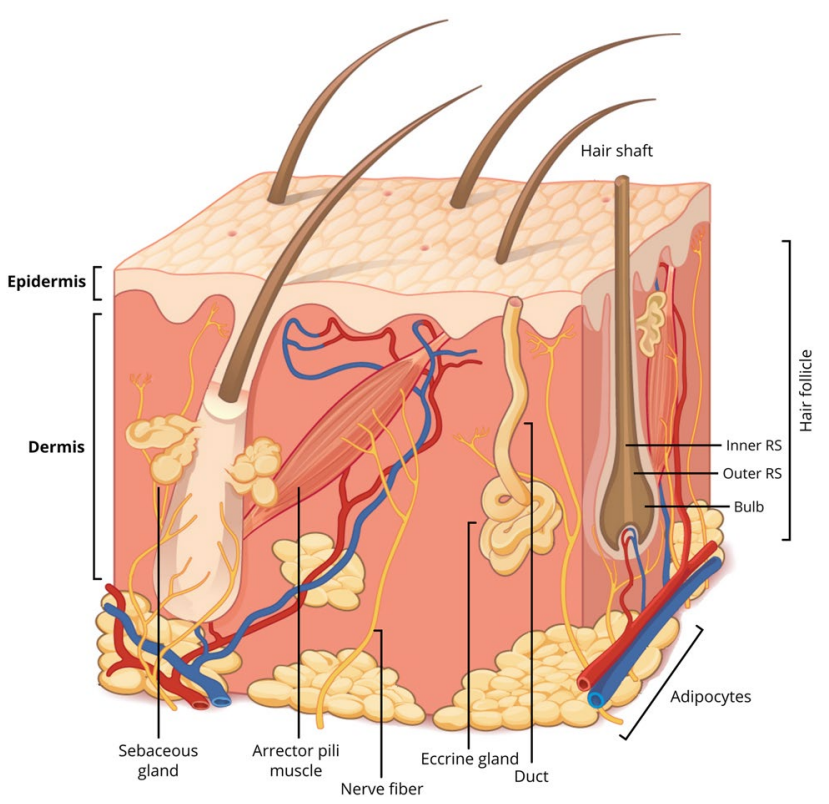

Fig. 1 Schematic view of a human skin section showing the epidermis, dermis, and the epidermal appendages-sebaceous glands, eccrine glands, hair follicles, and arrector pili muscle-examined in this study 
human CFTR (monoclonal mouse IgG2A) was from R\&D systems (MAB25031). Secondary antibodies, goat antirabbit IgG (Alexa Fluor 594 conjugate, A-11037), and goat anti-mouse IgG (Alexa Fluor 488 conjugate, A-11029) were purchased from Life Technologies.

Table 1 Sources of human skin samples used for immunofluorescence

\begin{tabular}{lllll}
\hline Subjects & Sex & $\begin{array}{l}\text { Age } \\
\text { (year) }\end{array}$ & Tissue & $\begin{array}{l}\text { Epidermal append- } \\
\text { ages identified }\end{array}$ \\
\hline HSKIF04 & M & 26 & Abdomen & E \\
HSKIF05 & M & 40 & Abdomen & E, EG \\
HSKIF06 & F & 1 day & Abdomen & E \\
HSKIF10 & F & 44 & Abdomen & E, EG, HF, AP \\
HSKIF11 & F & 70 & Abdomen & E, HF \\
HSKIF16 & M & 84 & Arm & E, EG, SG, Ad \\
HSKIF09 & M & 60 & Auricle & E, EG, SG, HF \\
HSKIF01 & F & 93 & Cheek & E, SG, HF \\
HSKIF12 & F & 45 & Cheek & E, EG, HF \\
HSKIF14 & F & 63 & Cheek & E, HF, AP \\
HSKIF03 & F & 89 & Neck & E, EG, SG, HF \\
HSKIF15 & M & 88 & Scalp & E, EG, SG, Ad \\
HSKIF07 & F & 77 & Temple & E, EG, SG, HF \\
HSKIF13 & M & 74 & Temple & E, EG, SG, HF, Ad \\
PH01 & M & 35 & Scalp & HF \\
\hline
\end{tabular}

$E$ epidermis, $E G$ eccrine gland, $S G$ sebaceous gland, $H F$ hair follicle, $A P$ arrector pili, $A d$ adipocytes

\section{Skin samples and sectioning}

Human skin samples were obtained post-operatively and were frozen immediately at $-20^{\circ} \mathrm{C}$ (for western blots) or placed in $4 \%$ formaldehyde in phosphate buffered saline (PBS) (10 mM potassium phosphate, $\mathrm{pH} 7.4$, and $150 \mathrm{mM}$ $\mathrm{NaCl}$ ) overnight (for immunofluorescence). The list of skin specimens is shown in Table 1.

Skin samples in formaldehyde were transferred to $30 \%$ sucrose and kept at $4{ }^{\circ} \mathrm{C}$ for at least $24 \mathrm{~h}$. Tissues were then embedded in OCT compound (Tissue-Tek, Sakura, Netherlands), frozen, and stored at $-80^{\circ} \mathrm{C}$. Tissue blocks were sliced to $15-30 \mu \mathrm{m}$-thick sections on a cryostat (Leica Jung Frigocut 2000 , Wetzlar, Germany) at $-25^{\circ} \mathrm{C}$ and collected in PBS containing $0.1 \%$ sodium azide. Hair-root samples were sliced into $40 \mu \mathrm{m}$-thick sections as described for skin samples.

The study was approved by the institutional ethics committee of the E. Wolfson Medical Center.

\section{Patients}

For this study, we have reviewed the history of dermatological findings in five patients with multi-system PHA who have been under our care for up to 30 years. All patients had deleterious mutations in genes encoding for $\mathrm{ENaC}$ subunits (Table 2). Except for patient DA, molecular analysis and endocrine findings of the patients were previously reported

Table 2 Skin manifestations in patients with multi-system PHA

\begin{tabular}{|c|c|c|c|c|c|}
\hline Patient & Age (year) & Sex & Mutated gene & References & Skin manifestations \\
\hline $\mathrm{AO}$ & 30 & $\mathrm{~F}$ & SCNN1A & $\begin{array}{l}\text { Hanukoglu (1991); Hanukoglu et al. (1994); } \\
\text { Chang et al. (1996) }\end{array}$ & $\begin{array}{l}\text { Miliaria rubra over the body at ages } 1.6,2.9,3.7 \text { years. } \\
\text { Intermittent atopic dermatitis like rashes over the } \\
\text { neck and lower extremities until the age of } 8 \text { y espe- } \\
\text { cially during hot summer days } \\
\text { No skin eruptions since then }\end{array}$ \\
\hline RG & 26 & M & SCNN1A & Hanukoglu et al. (1994); Kerem et al. (1999) & $\begin{array}{l}\text { Miliaria rubra, folliculitis over the lower extremities } \\
\text { due to excessive sweating especially during hot sum- } \\
\text { mer days. Less frequent with age } \\
\text { Allergic to milk protein, dust mite resulting in urticaria } \\
\text { when exposed to allergens }\end{array}$ \\
\hline RT & 26 & M & SCNN1A & (Hanukoglu et al. 1994; Kerem et al. 1999) & $\begin{array}{l}\text { Miliaria rubra, folliculitis over the lower extremities } \\
\text { due to excessive sweating especially during hot sum- } \\
\text { mer days. Less frequent with age }\end{array}$ \\
\hline HS & 16 & M & SCNN1B & (Edelheit et al. 2005; Hanukoglu et al. 2008) & $\begin{array}{l}\text { Intermittent folliculitis, atopic dermatitis like rash over } \\
\text { forehead, face, palms, neck, shoulders, cubital and } \\
\text { popliteal regions, thighs since the age of } 2-3 \text { years } \\
\text { especially during hot summer days }\end{array}$ \\
\hline DA & 6 & $\mathrm{~F}$ & SCNN1B & Unpublished & $\begin{array}{l}\text { Intermittent folliculitis, pustular lesions, erythematotic } \\
\text { skin lesions over the forehead, face, perinasal and } \\
\text { perioral areas and back } \\
\text { Seborrhea of the scalp } \\
\text { No extensive skin lesions over the body to date }\end{array}$ \\
\hline
\end{tabular}


(Table 2). Dermatologic findings were not included in these previous reports.

\section{Immunofluorescence staining}

Tissue sections were permeabilized with $0.1 \%$ Tween-20 (Sigma-Aldrich) in PBS for 10 min and washed three times in PBS for 5 min each. The sections were then incubated in $100 \mu \mathrm{l} \%$ bovine serum albumin (BSA) (Sigma-Aldrich) in PBS for $20 \mathrm{~min}$, washed with PBS for $5 \mathrm{~min}$, and incubated overnight at $4{ }^{\circ} \mathrm{C}$ with primary antibody (1:25 dilution) in PBS containing $2 \%$ BSA. Sections were then washed three times in PBS (5 min each) and incubated with the secondary antibodies (at 1:100 dilution) in PBS containing $2 \% \mathrm{BSA}$ for $1 \mathrm{~h}$. After three $5 \mathrm{~min}$ washes with PBS, nuclei were stained using DAPI (4'6-diamidino2-phenylindole) for $1 \mathrm{~min}$. Unless otherwise indicated, all the steps were carried out at room temperature. In control experiments, the same protocol was repeated without adding the primary antibody. In such control slides, only the blue DAPI staining was visible.

F-actin staining of tissue slices was performed using a CF488A Phalloidin conjugate (Biotium, Hayward, CA, 1:20 dilution) in PBS containing 2\% BSA for $20 \mathrm{~min}$ immediately after washing the secondary antibodies.

The sections were then transferred onto X-tra Adhesive slides (Leica Biosystems, Peterborough, UK), dried at room temperature for $\sim 5 \mathrm{~min}$, and covered with mounting solution glycerol containing n-propyl gallate (Sigma-Aldrich) in $100 \mathrm{mM}$ phosphate buffer ( $\mathrm{pH}$ 7.2). All the experiments were performed at least three times with independent samples.

\section{Confocal microscopy}

High-resolution fluorescent images were captured using LSM 700 confocal microscope (Carl-Zeiss, Germany). The laser diodes used were $405 \mathrm{~nm}$ for excitation of DAPI, $555 \mathrm{~nm}$ for excitation of Alexa fluor 594, and $488 \mathrm{~nm}$ for excitation of CF488A and Alexa Fluor 488. Fluorescence and bright-field illumination modes were used during image acquisition process. Sections were visualized through EC Plan-Neofluar 40×, or Plan-Apochromat $63 \times$ oil objective lenses. Three-dimensional images were acquired along $Z$-axis (Z-stacking) using $40 \times$ objective, and pinhole size was adjusted for each channel to the diffraction limit of 2.08 Airy units.

\section{Protein gel electrophoresis and Western blots}

Frozen skin samples from the abdominal region were homogenized in $50 \mathrm{mM}$ Tris, $\mathrm{pH} 7.4,1 \mathrm{mM}$ EDTA, and protease inhibitor cocktail at $4{ }^{\circ} \mathrm{C}$ and stored at $-80^{\circ} \mathrm{C}$.
Protein concentration was determined by the Bradford assay (Bio-Rad) using BSA as a standard. For electrophoresis, protein samples were dissolved in gel sample buffer (50 mM Tris- $\mathrm{HCl}$ pH 6.8, 2\% SDS, 0.2\% bromophenol blue, $10 \%$ glycerol, and $100 \mathrm{mM}$ DTT), heated at $98^{\circ} \mathrm{C}$ for 5 min, and loaded onto $8.5 \%$ polyacrylamide gel.

Proteins were separated by electrophoresis and transferred onto nitrocellulose membrane (Bio-Rad) using a Bio-Rad apparatus. Initially, the membrane was blocked using $1 \%$ milk in PBS for 45 min at room temperature. The blot was then incubated with rabbit anti- $\alpha$-ENaC antisera (1:1000) in PBS containing $2 \%$ bovine serum albumin at $4{ }^{\circ} \mathrm{C}$ overnight. The blot was washed four times in PBST (0.1\% Tween-20 in PBS, 5 min per wash).

The blot was incubated with secondary antibody (Fluorescence DRX-800 goat anti-rabbit IgG from Li-COR Biosystem) (diluted 1:10,000) in freshly prepared PBS containing $2 \% \mathrm{BSA}$ for $90 \mathrm{~min}$ at room temperature. The membrane was washed four times in $0.1 \%$ PBST for $5 \mathrm{~min}$ each and then taken for scanning in an LI-COR fluorescence imaging biosystem.

\section{Check for glycosylation by PNGaseF digestion}

In the initial western blots of skin samples, we observed bands at molecular weights higher than that observed in the kidney and lung. To examine the possibility that these bands may represent glycosylated proteins, we prepared samples treated with Peptide-N-Glycosidase F (PNGase F) that cleaves between the innermost GlcNAc and asparagine residues in N-linked glycoproteins (P0705S from New England Biolabs). For this purpose, $200 \mu \mathrm{g}$ of human skin samples were mixed with Glycoprotein denaturing buffer (10×) and kept at $100^{\circ} \mathrm{C}$ for 10 min and then chilled on ice. The digestion was carried out in the glycoprotein reaction buffer, including NP-40 and the enzyme PNGase F as recommended by the manufacturer at $37^{\circ} \mathrm{C}$ for $4 \mathrm{~h}$.

\section{Results and discussion}

In this study, we examined "thin" skin samples from different areas of the body, including abdomen, arm, ear, cheek, temple, scalp, and neck $(N=15$; seven males, eight females) (Table 1). We mapped the sites of localization of $\mathrm{ENaC}$, and CFTR using antibodies noted in "Methods". The nuclei were stained using DAPI, and F-actin cytoskeleton was stained using a fluorescent phalloidin conjugate.

Below, we present and discuss our results grouped into the following subsections: (1) epidermis and dermis; (2) hair follicles; (3) sebaceous glands; (4) eccrine glands; (5) arrector pili; and (6) intra-dermal adipocytes. 


\section{Expression of $\mathrm{ENaC}$ in the epidermis}

Immunofluorescence imaging using anti- $\alpha \mathrm{ENaC}$ antibodies revealed that $\mathrm{ENaC}$ is expressed uniformly in all the cells of the epidermal sub-layers (stratum basale, stratum spinosum, and stratum granulosum) except the top keratinized (cornified) layer (stratum corneum) that is composed of dead and flattened cells without nuclei (Fig. 2) (Candi et al. 2005). This observation applies to all the body areas examined (Table 1).

In contrast to epidermis, we did not detect $\mathrm{ENaC} \mathrm{immu-}$ nofluorescence in the dermis that lies below the epidermis (Fig. 2). However, as detailed below, ENaC expression was also detected in various epidermal appendages that are partly embedded in the dermal layer.

The stratum basale of the epidermis contains mainly keratinocytes, but also melanocytes and rare Merkel cells. Since all the cells of the lower epidermal layers showed $\mathrm{ENaC}$ immunofluorescence uniformly, it appears that non-keratinocyte cells of the epidermis, including melanocytes and Merkel cells, also express ENaC. An earlier study already showed expression of $\mathrm{ENaC}$ subunit mRNAs in a human melanoma cell line derived from melanocytes (Yamamura et al. 2008b).

Higher magnification imaging of the keratinocytes of the epidermis revealed that $\mathrm{ENaC}$ is located nearly uniformly in the cytoplasm in a granular distribution that may represent tiny vesicles (Fig. 3). This distribution within the cytoplasm is very different from the pattern of expression of $\mathrm{ENaC}$ in epithelial cells in the female reproductive system, where $\mathrm{ENaC}$ is localized specifically to the apical membrane and to the cilia in ciliated cells with hardly any staining in the cytoplasm except for few isolated vesicles (Enuka et al. 2012).

It is noteworthy that $\mathrm{ENaC}$ immunofluorescence abruptly ends at the keratinocyte cell border and no staining is detected in the inter-cellular space between keratinocytes
(Fig. 3). In the epidermis, the keratinocytes are interconnected by adherens junctions (Fuchs and Nowak 2008). The inter-cellular space is occupied by the interdigitated extracellular segments of cadherins, i.e., glycoproteins that are embedded in the membrane with a single transmembrane segment. The cytoplasmic tails of these cadherins are connected via linker proteins to F-actin (Hulpiau and van Roy 2009; Takeichi 2014; Samuelov et al. 2015). Thus, the scaffold of the cadherins in the inter-cellular space is anchored to the cytoplasmic actin filaments that run in parallel to the cell membrane. We were the first to clone and sequence an actin cDNA expressed in the human epidermis (Hanukoglu et al. 1983). In keratinocytes, the actin filaments are visualized using fluorescent phalloidin (Fig. 3). Because of the short distance between the actin filaments in neighboring cells, the actin filaments of both neighbors are seen as a common thick border between the neighboring cells (Fig. 3). The cell membranes of the neighboring cells should, therefore, be located in about the middle of the phalloidin staining of actin filaments. The absence of $\mathrm{ENaC}$ immunofluorescence in between the cells indicates that either $\mathrm{ENaC}$ is not localized here, or that it cannot be detected because of the dense filaments.

It is also noteworthy that there was no overlap between $\mathrm{ENaC}$ (red) and DAPI (blue) immunofluorescence, indicating that $\mathrm{ENaC}$ is not localized in cell nuclei. A recent article has reported co-localization of ENaC immunofluorescence with DAPI stained nuclei in epidermal sections (Li et al. 2014). We have not observed any localization of $\mathrm{ENaC}$ in nuclei in any tissue that we have so far examined.

In a recent study that examined localization of sodium channels ( $\mathrm{ENaC}$ and $\mathrm{Nax}$ ) by immunofluorescence, by far, the most intensive site of ENaC localization appeared at the stratum corneum at the edge of the skin section and above the suprabasal cell layer [see intense green color in Figs. 3a, 4c of the study by (Xu et al. 2015b)]. We have not seen such immunofluorescence in the stratum corneum
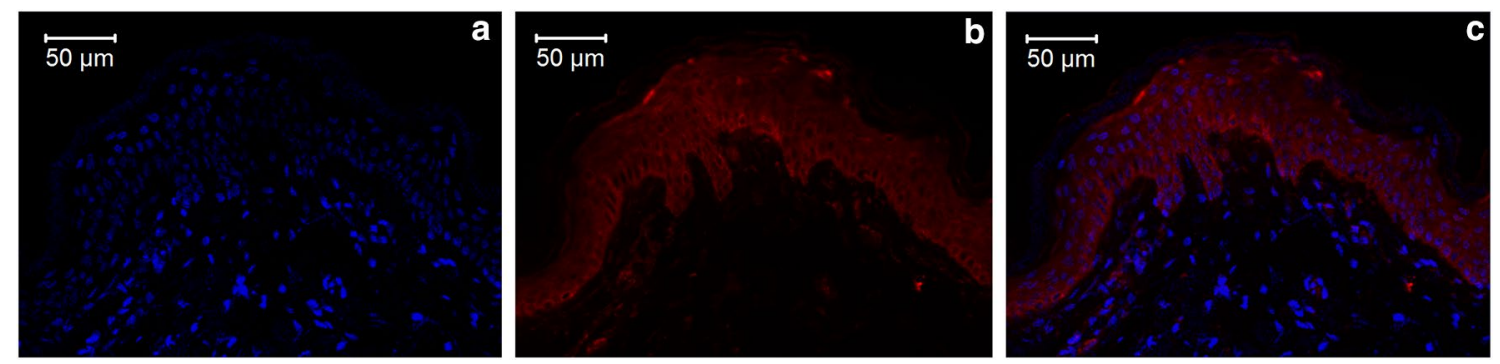

Fig. 2 Expression of $\mathrm{ENaC}$ in the human skin. A skin section was reacted with DAPI (blue) and anti- $\alpha$-ENaC (red), as described in "Methods". a Blue-colored DAPI staining of cell nuclei. b Anti- $\alpha-$ $\mathrm{ENaC}$ immunofluorescence (red). c Merged image of (a) and (b). Note that red fluorescence for $\mathrm{ENaC}$ is observed only in the epidermal layer. The DAPI stained areas marking the cell nuclei are devoid of ENaC immunofluorescence. The dermis below the epidermis was not stained with anti- $\alpha-E N a C$. All layers of the epidermis above the dermis, from the basal layer (stratum basale) to the subcorneal layer, showed uniform staining for ENaC. Skin sample: HSKIF04 from the abdomen. Scale bars $50 \mu \mathrm{m}$ 

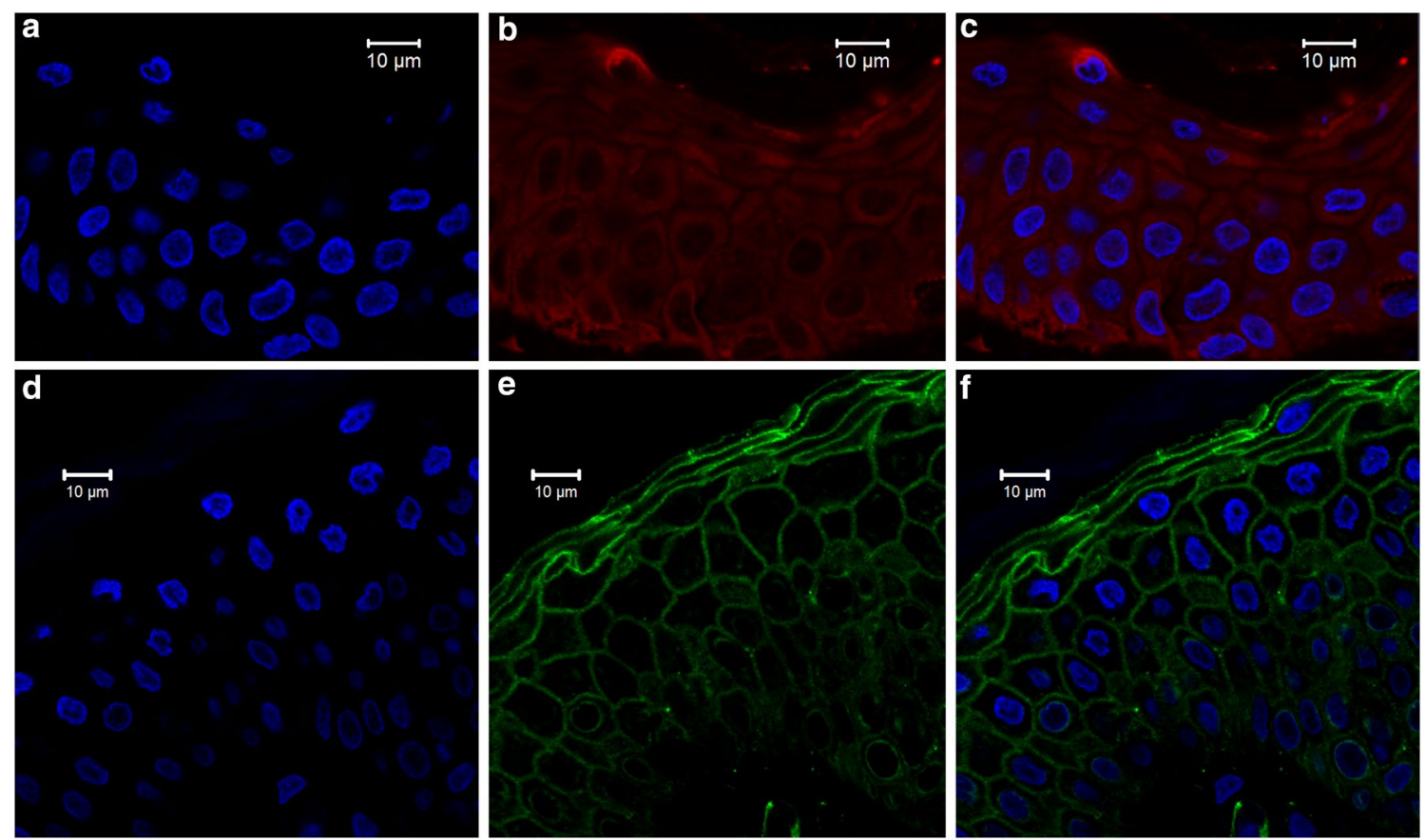

Fig. 3 Enlarged view of keratinocytes reacted with: Top row-a DAPI (blue) and $\mathbf{b}$ anti- $\alpha$-ENaC (red). Bottom row d DAPI (blue) and e CF488A Phalloidin conjugate (green). In both rows, the rightmost image $(\mathbf{c}, \mathbf{f})$ shows the merged image of the two first images.

Note that $\mathrm{ENaC}$ fluorescence is inside the cells. In between the cells, there is no red $\mathrm{ENaC}$ fluorescence. In contrast, the green phalloidin fluorescence is localized in between the keratinocytes. Skin sample HSKIF05, HSKI04 from the abdomen. Scale bars $10 \mu \mathrm{m}$
Fig. 4 Expression of ENaC in a hair follicle. a Blue-colored DAPI staining of cell nuclei. (b) Anti- $\alpha$-ENaC immunofluorescence (red). c Merged image of (a) and (b). In addition to the epidermal layer, red $\mathrm{ENaC}$ fluorescence $(\mathbf{b}, \mathbf{c})$ is also located in the hair follicle cells that are embedded in the dermis. The image at the bottom right (d) shows a bright-field image of the same hair follicle with the hair shaft. Skin sample HSKIF03 from the neck. Scale bars $100 \mu \mathrm{m}$
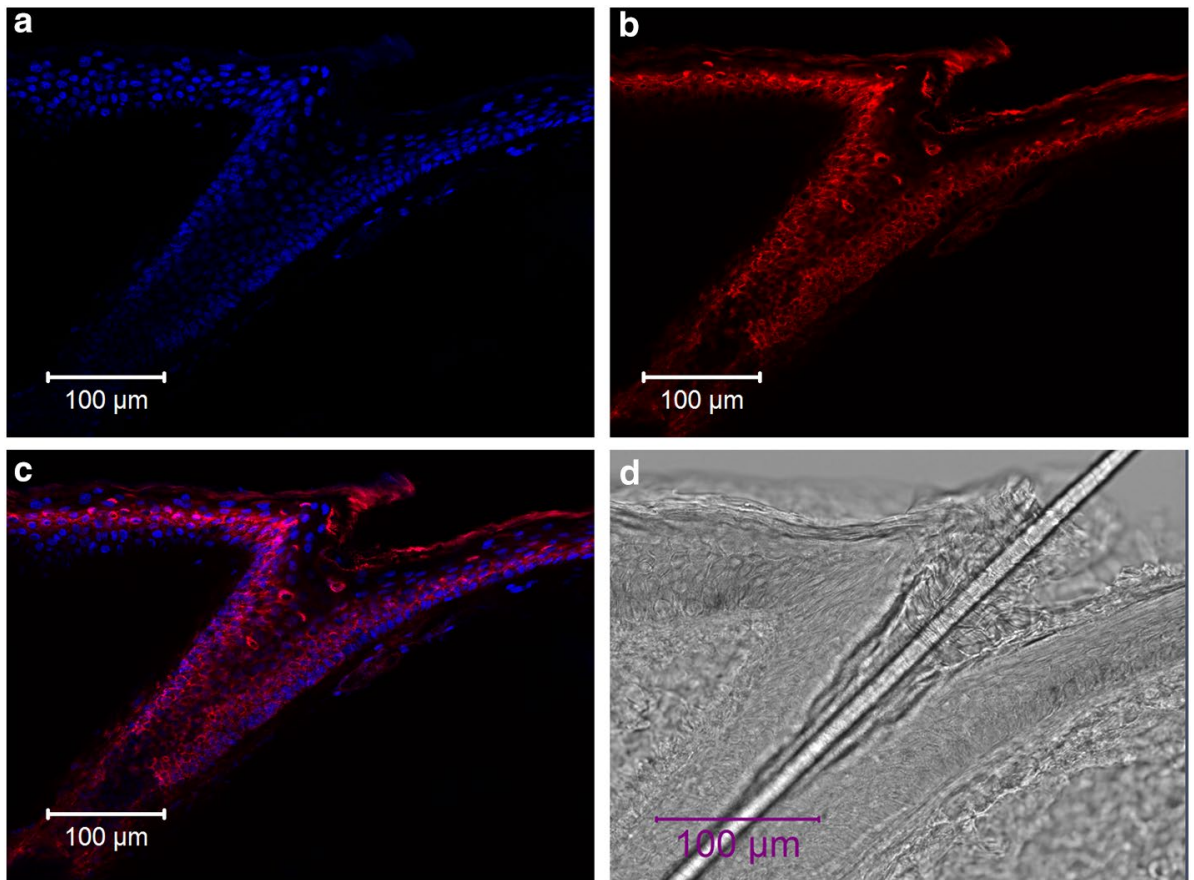

that is composed of dead and flattened cells without nuclei (Candi et al. 2005). The authors of the study (Xu et al. 2015b) did not comment about the meaning of apparent localization of sodium channels in this dead layer of cells 
of stratum corneum that may be the result of a non-specific interaction.

\section{Expression of $\mathrm{ENaC}$ in hair follicles}

Hair follicles develop from stem cells located in discrete compartments (niches) (Waters et al. 2007). A hair follicle is formed in several concentric layers; the main ones of which include the outer root sheath, the inner root sheath, and the hair shaft (Schneider et al. 2009). Figure 4 shows $\mathrm{ENaC}$ immunofluorescence in a hair follicle together with the bright-field view of the hair shaft. To understand the distribution of $\mathrm{ENaC}$ in a hair follicle, we also examined the $\mathrm{ENaC}$ distribution by immunofluorescence staining of a hair follicle in a cross section of a plucked hair (Fig. 5). In these cross sections, $\mathrm{ENaC}$ immunofluorescence was only observed in the outer (external) root sheath but not in the inner root sheath and the hair shaft (Fig. 5). The cortex and the medulla of the hair shaft were devoid of any staining (Fig. 5).

\section{Expression of ENaC and CFTR in the sebaceous glands}

Sebaceous glands develop from epithelial stem cells located above the bulge area of the hair follicle (Smith and Thiboutot 2008; Eckert et al. 2013). In the acini of these glands, the peripheral cells are small and mitotically active and differentiate to form the large so-called "central cells" that are full of cytoplasmic lipid droplets. These central cells excrete sebum via the excretory duct of the gland connected to the hair follicle.

$\mathrm{ENaC}$ immunofluorescence is strong in both peripheral and central cells of the sebaceous gland (Fig. 6). ENaC staining is observed only in the cytoplasmic space in between the lipid vesicles (Fig. 6). As in other parts of the epidermis, the DAPI stained area of the cell nucleus is free of ENaC immunofluorescence (Fig. 6).

While ENaC immunofluorescence is uniform in the central cells, CFTR immunofluorescence is strongest in the cell border of the central glands, and the cytoplasmic staining is weaker (Fig. 7). We have also observed CFTR immunofluorescence in the epidermal cells but at a much lower intensity (Fig. 7). Double reaction with both anti-ENaC and anti-CFTR showed that both channels are co-localized (results not shown).

\section{Expression of ENaC and CFTR in eccrine sweat glands}

Eccrine sweat glands are formed by a coiled, convoluted structure of secretory cells. The coil is connected to the skin surface by a sweat duct (Cui and Schlessinger 2015). We could identify the eccrine glands in skin sections by typical clusters of tubular structures in the dermal layer, which are formed by two concentric layers of cells (Fig. 7). In contrast to the epidermal cells, $\mathrm{ENaC}$ immunofluorescence in these cells was strongest on the apical surface of the cells facing the lumen (Fig. 8). In a different section, an isolated duct showed strong expression of ENaC (Fig. 9). Since this duct was surrounded by two concentric layers of cells, without a similar duct around it, we assume that it is part of the secretory duct of an eccrine gland. Similar to $\mathrm{ENaC}, \mathrm{CFTR}$ is also located on the apical membrane facing the lumen (Fig. 10).

The two layers of cells surrounding the eccrine gland duct have been named suprabasal and basal cells (Cui and Schlessinger 2015). In our results, both ENaC and CFTR immunofluorescence are detected on the luminal side of the duct. Thus, in eccrine glands, these channels are apparently expressed in suprabasal cells.
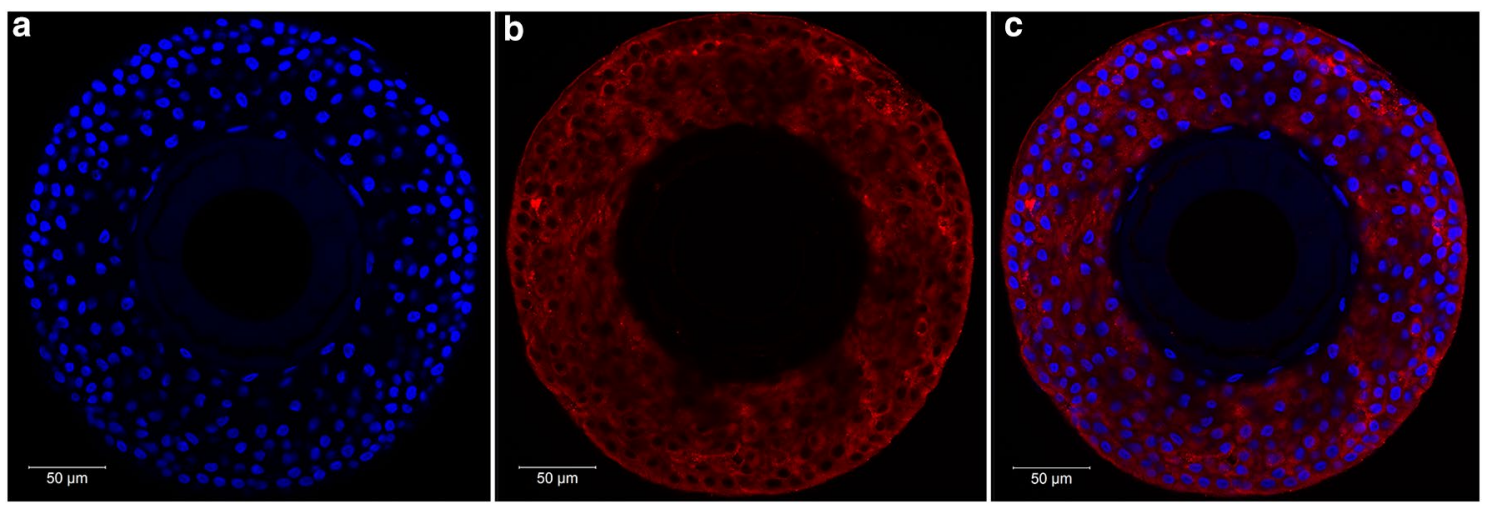

Fig. 5 Cross section of a hair follicle. a Blue-colored DAPI staining of cell nuclei. b Anti- $\alpha$-ENaC immunofluorescence (red). c Merged image of $(\mathbf{a}, \mathbf{b})$. Red immunofluorescence for $\mathrm{ENaC}$ is observed only in cells in the outer epithelial sheath. The cell nuclei, and the cuticle, cortex, and medulla of the hair follicle show no ENaC staining. Sample PH01 from occipital region of scalp. Scale bars $50 \mu \mathrm{m}$ 

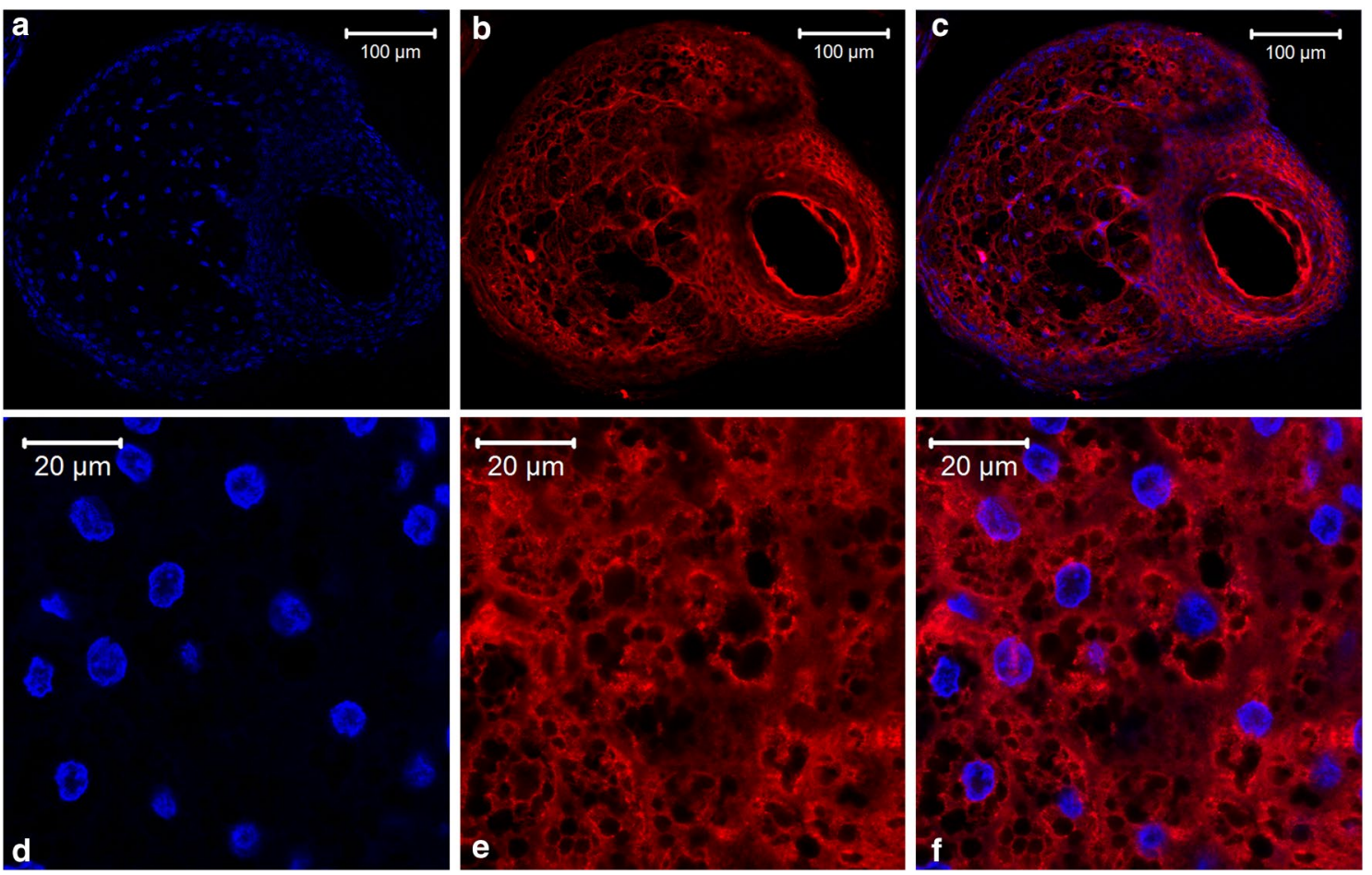

Fig. 6 Expression of $\mathrm{ENaC}$ in the sebaceous glands. The images in the top row $(\mathbf{a}, \mathbf{b}, \mathbf{c})$ show a cross section of a sebaceous gland connected to a hair follicle located at the bottom right quarter of the image. Note that the peripheral cells at the edge of the gland are flat and do not contain vesicles. The so-called central cells inside the gland have cytoplasmic vesicles. Relative to the hair follicle cells (surrounding the unstained space of the hair shaft), central cells of the gland are huge. The bottom row (d, e, f) shows an enlarged view of a region with about 22 nuclei of central cells. Note that each nucleus (blue) is surrounded by vesicles that do not show any staining. ENaC immunofluorescence (red) is observed in the cytoplasm surrounding the vesicles. Skin samples HSKIF03 and HSKIF14 from the neck and cheek. Scale bars $100 \mu \mathrm{m}$ for the images on top and $20 \mu \mathrm{m}$ for those below
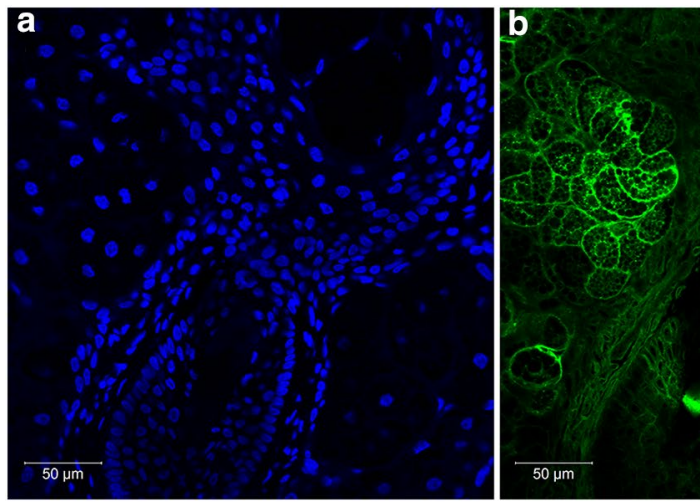

Fig. 7 Expression of CFTR in the sebaceous glands. a Blue-colored DAPI staining of cell nuclei. b Anti-CFTR immunofluorescence (green). c Merged image of (a, b). In this image, there are four glands around a hair follicle. CFTR immunofluorescence (green) is observed on both epidermal cells and hair follicle cells, but it is strongest on the surface of central cells with cytoplasmic vesicles. The strong

\section{Expression of ENaC in arrector pili muscle cells}

Arrector pili are small bundles of smooth muscle cells that are connected to the hair follicle at one end and to the green CFTR immunofluorescence delineates the boundaries of the central cells in the gland. Note that there is no overlap between the blue DAPI stain and the green CFTR stain, i.e., CFTR is not located in cell nuclei. Skin sample HSKIF13 from the temple. Scale bars $50 \mu \mathrm{m}$

connective tissue in the dermal layer of the skin at the other end. Contraction of this muscle pulls the hair to stand erect, causing the so-called goosebumps effect (Torkamani et al. 2014). The actin cytoskeleton is a central component of the 

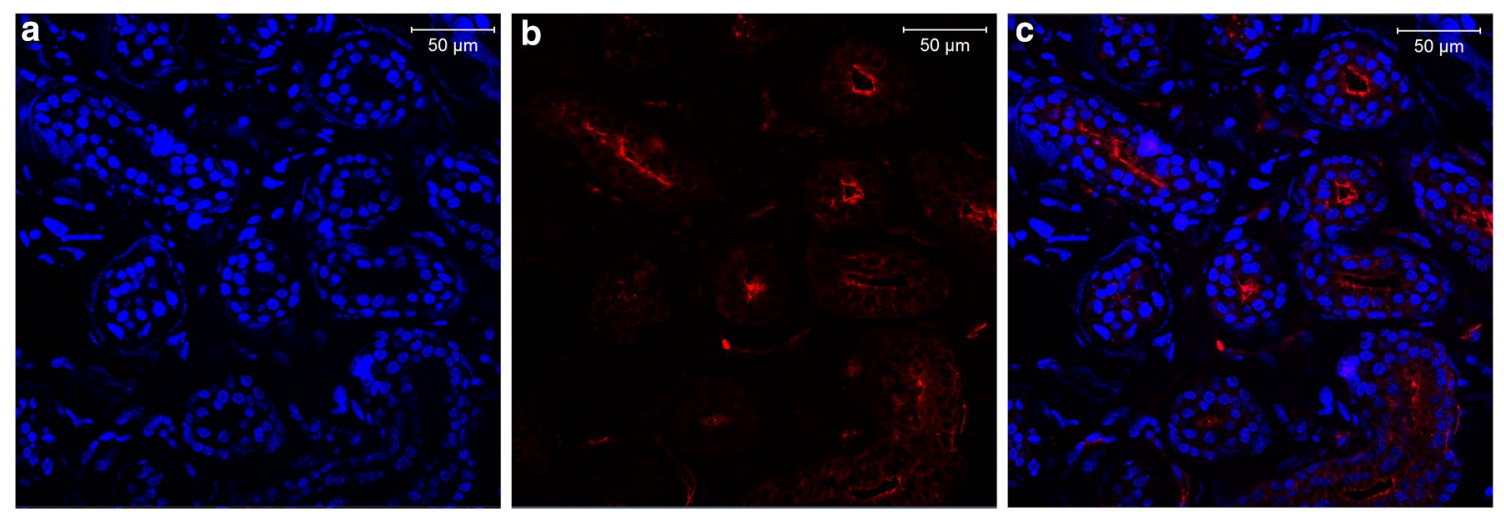

Fig. 8 Expression of $\mathrm{ENaC}$ in a cross section of eccrine sweat glands that have a coiled tubular structure. a Blue-colored DAPI staining of cell nuclei. b Anti- $\alpha$-ENaC immunofluorescence (red). c Merged image of (a, b). In contrast to keratinocytes (see Figs. 2, 3, 4, 5), in

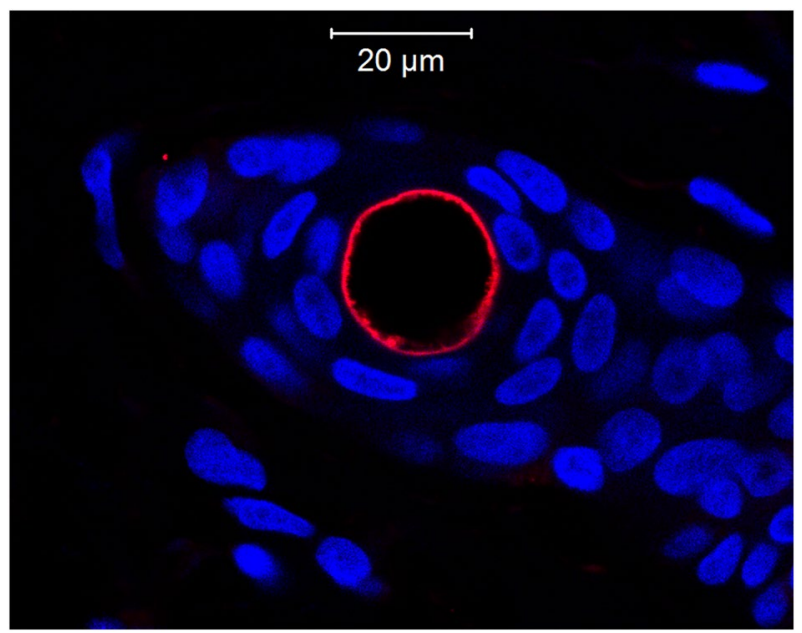

Fig. 9 Expression of ENaC in a cross section of an eccrine gland duct. ENaC immunofluorescence is seen in the lumen of the duct as a red circle. This image is assumed to represent an eccrine gland duct based on the fact that the lumen is surrounded by two rows of cells as in eccrine glands, but it was isolated in the section appearing by itself without other similar structures around it. Skin sample HSKIF13 from the temple. Scale bar $20 \mu \mathrm{m}$

smooth muscle contractile apparatus (Lehman and Morgan 2012; Arnoldi et al. 2013). To identify arrector pili muscle bundles, we reacted skin sections with fluorescently labeled phalloidin that binds to F-actin filaments. The phalloidin fluorescence (green) was specifically localized to smooth muscle cell bundles next to a hair follicle (Fig. 11). $\mathrm{ENaC}$ immunofluorescence was also strong in these muscle bundles (Fig. 11). In a cross section of smooth muscle cells, both F-actin and ENaC fluorescence were specifically localized to the cytoplasm (Fig. 12). At present resolution, it is not possible to state conclusively that $\mathrm{ENaC}$ is also localized on the cell membrane. eccrine glands, expression of $\mathrm{ENaC}$ is strongest on the apical cell surface facing the lumen. Skin sample HSKIF09 from an auricle. Scale bars $50 \mu \mathrm{m}$

\section{Expression of ENaC and CFTR in intra-dermal adipocytes}

Commonly, subcutaneous adipose tissue has been referred to as subcutaneous fat in the hypodermis (Wronska and Kmiec 2012). Recent research has revealed that the origin of adipocytes in the dermal layer is different from those in the subcutaneous tissue (Kruglikov et al. 2016). Therefore, a clear distinction has been drawn between dermal adipocytes versus subcutaneous white adipose tissue (Driskell et al. 2014). This distinction is especially evident in mouse skin sections: in the subcutaneous adipose tissue below the panniculus carnosus, adipocytes dominate in rather uniform layers of cells. In contrast, in the dermis, small clusters of adipocytes are interspersed between diverse cell types common in the dermis (Mori et al. 2014).

Mature adipocytes generally contain a single large lipid droplet that fills most of the cell volume. Thus, the cytoplasm occupies a very thin layer alongside the cell membrane. The cell nucleus and other subcellular organelles are "squeezed" into this thin layer of the cytoplasm (MartinezSantibañez et al. 2014). In the lower dermal layer of some human skin samples, we could easily visualize groups of adipocytes interspersed among ductal structures. In these adipocytes, $\mathrm{ENaC}$ immunofluorescence was strong in the cytoplasm that lines the cell membrane (Fig. 13). Staining of the sections with fluorescent phalloidin showed that in dermal adipocytes, there is a sheet of actin fibers juxtaposed to the cell membrane as previously reported in other types of adipocytes (Kanzaki and Pessin 2001). In the merged view of ENaC and F-actin-phalloidin immunofluorescence, at red-green overlaps, the color changes to yellow suggesting co-localization (Fig. 13).

Overall, our results establish that $\mathrm{ENaC}$ is expressed in the dermal adipocytes. Yet, because of the thin 

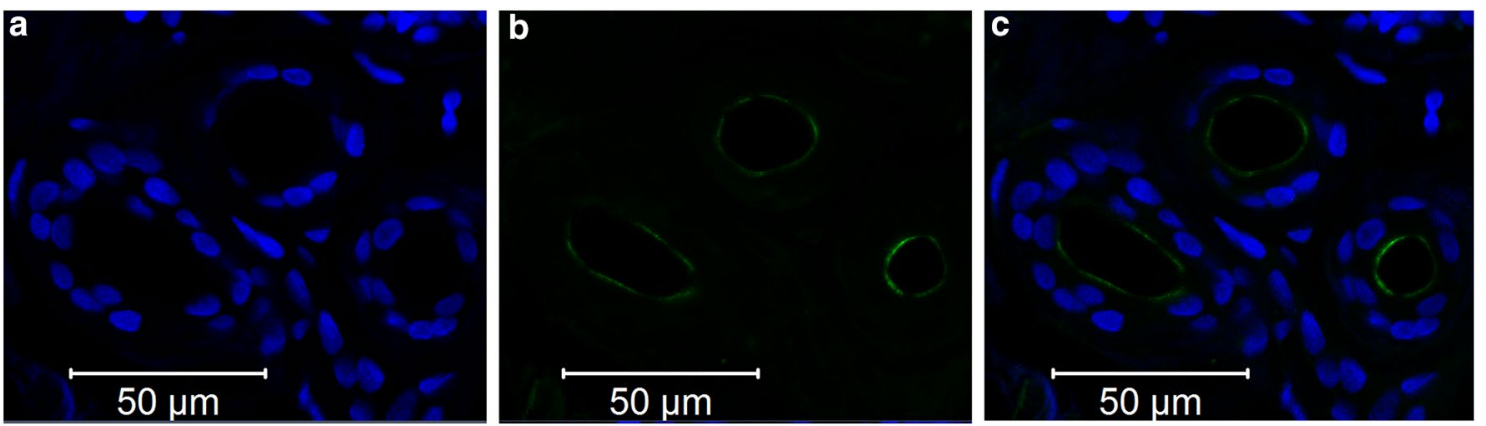

Fig. 10 Expression of CFTR in a cross section of eccrine sweat glands. a Blue-colored DAPI staining of cell nuclei. b Anti-CFTR as shown in Fig. 8 for ENaC, CFTR immunofluorescence (green) is localized in the lumen of two concentric layers of cells. Skin sample immunofluorescence (green). c Merged image of $(\mathbf{a}, \mathbf{b})$. Note that

HSKIF15 from the scalp. Scale bars $50 \mu \mathrm{m}$

Fig. 11 Expression of actin (green) and $\mathrm{ENaC}($ red) in arrector pili muscle cells. a DAPI staining, b actin, $\mathbf{c} \mathrm{ENaC}$, and $\mathbf{d}$ Merged immunofluorescence of all three colors. The smooth muscle cell bundle is located at the top left side of a hair follicle cross section. Blue-colored DAPI imaging was over-exposed marking the surrounding connective tissue in addition to cell nuclei. Note that image with the merger of all three colors shows a color change for the actin and $\mathrm{ENaC}$ staining indicating that both colors are overlapping.

This is expected as both actin and $\mathrm{ENaC}$ are localized in the cytoplasm, as shown in Fig. 12. Skin sample HSKIF14 from the cheek. Scale bars $50 \mu \mathrm{m}$
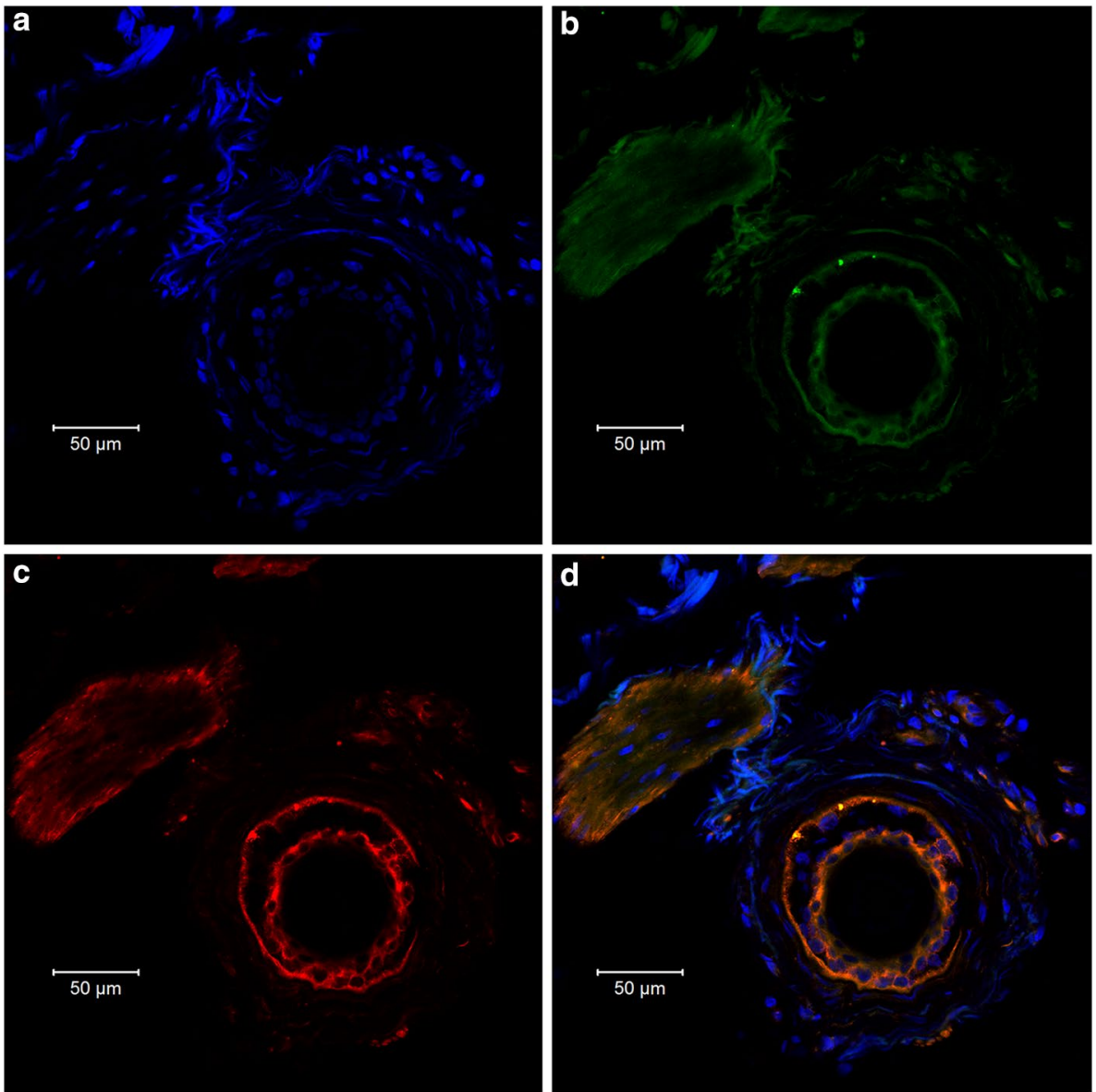

ultrastructure of the adipocytes, we cannot state the precise location of $\mathrm{ENaC}$, whether it is in the cytoplasm or the cell membrane, or both. Similar to ENaC, CFTR immunofluorescence is also located in a thin strip along the adipocyte surface (Fig. 14).

\section{Western blot analysis of ENaC expression in skin}

$\mathrm{ENaC}$ subunits are heavily glycosylated, and the glycosylation sites of these proteins are mostly conserved across species (Canessa et al. 1994; Snyder et al. 1994; Hanukoglu 
Fig. 12 Expression of actin (green) and $\mathrm{ENaC}$ (red) in a cross section of arrector pili muscle cells. The section was stained with DAPI (blue), fluorescently labeled CF488A Phalloidin conjugate (green), and anti- $\alpha$-ENaC (red). a DAPI + phalloidin staining. $\mathbf{b}$ $\mathrm{DAPI}+\mathrm{ENaC}$ immunofluorescence. Note that in the smooth muscle cells, actin fills the cytoplasm. Similarly, ENaC expression is strong in the cytoplasm. As in the previous images, the cell nuclei are marked by the blue color of DAPI. Skin sample HSKIF10 from the abdomen. Scale bar $100 \mu \mathrm{m}$
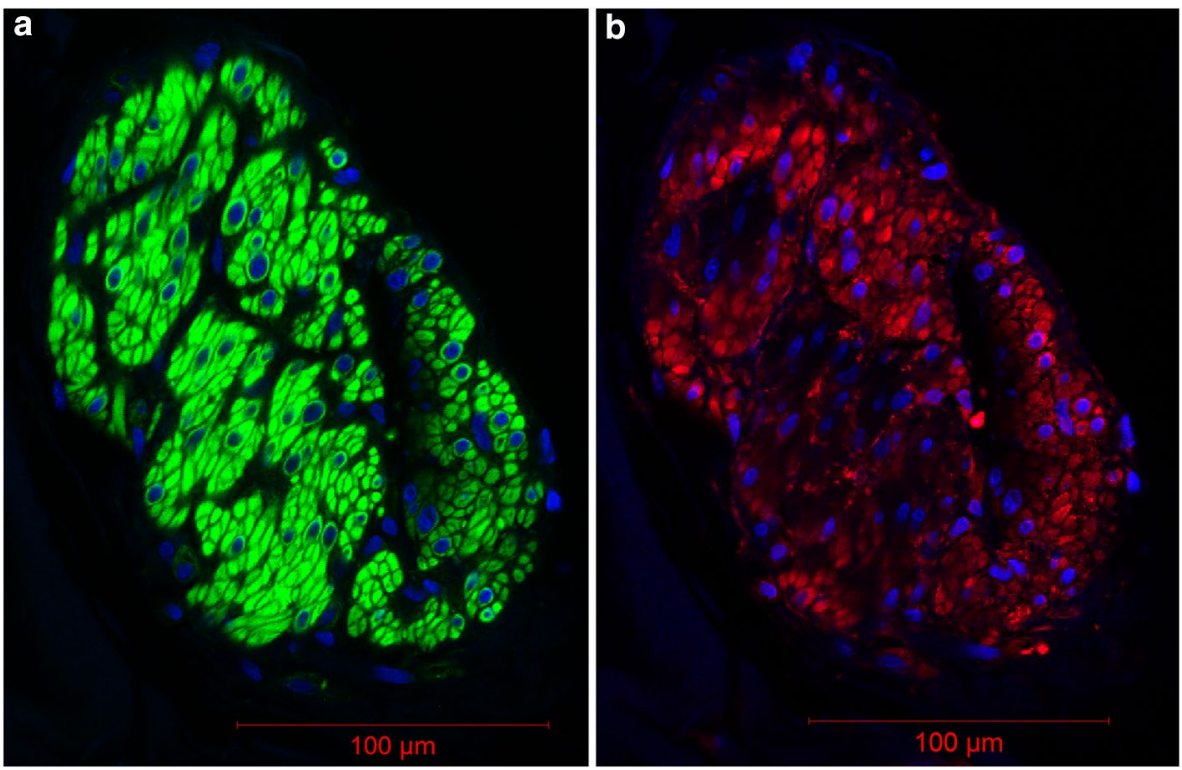

Fig. 13 Expression of ENaC (red) and F-actin (green) in intra-dermal adipocytes. a DAPI staining, b ENaC, c actin, and d merged immunofluorescence of all three colors. F-actin fibers labeled by fluorescent phalloidin (green) are aligned alongside with the cell membrane. Similarly, ENaC is also localized in a thin cytoplasmic strip in between the cell membrane and the lipid vesicle that fill the cell. The merged image shows that the nuclei stained with DAPI remain with the same blue color. However, instead of red and green colors, a yelloworange color appears indicating that localizations of $\mathrm{ENaC}$ and actin filaments are overlapping. Skin sample HSKIF15 from the scalp. Scale bars $50 \mu \mathrm{m}$
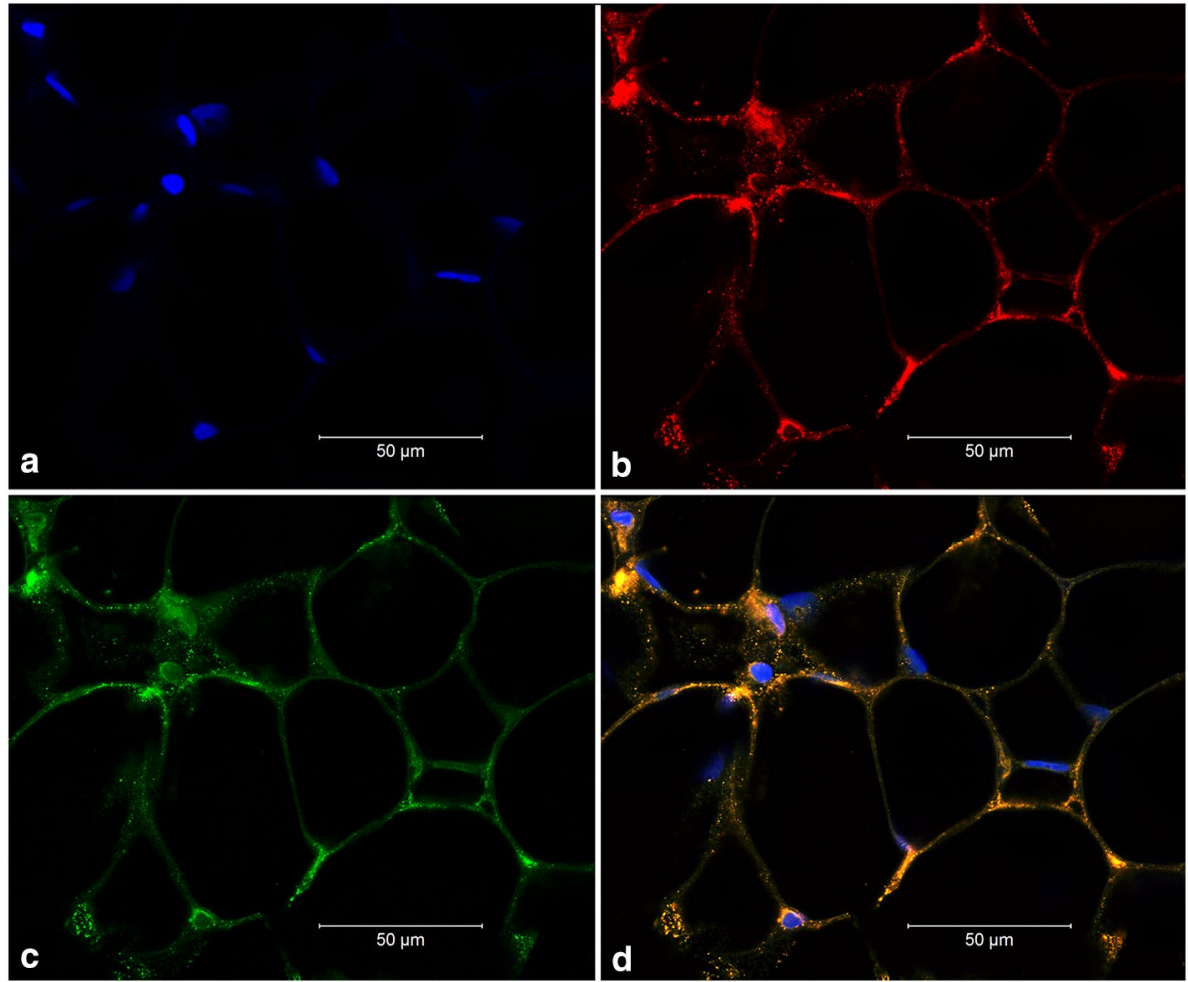

and Hanukoglu 2016). In addition, ENaC subunits are cleaved by proteases at specific sites (Chen et al. 2014; Hanukoglu and Hanukoglu 2016). Thus, on Western blot reacted with anti-ENaC antibodies, in general, several cross-reactive bands are observed. These bands represent the following forms of the protein: (1) unglycosylated protein at $\sim 70-78 \mathrm{kDa}$; (2) glycosylated forms at $90-100 \mathrm{kDa}$; and (3) protease cleaved forms at $<50 \mathrm{kDa}$.
In our repeated western blots of the human skin samples, we observed major bands at $\sim 50$ and 90-100 kDa range but did not observe a band at $\sim 75 \mathrm{kDa}$. These observations were consistent with the previous observations based on protein samples from the human epidermis and cultured keratinocytes that showed bands at $\sim 90 \mathrm{kDa}$ but no band at $\sim 75 \mathrm{kDa}$ (Oda et al. 1999). To verify that these bands represent $\mathrm{ENaC}$ subunit forms, we carried out competition 

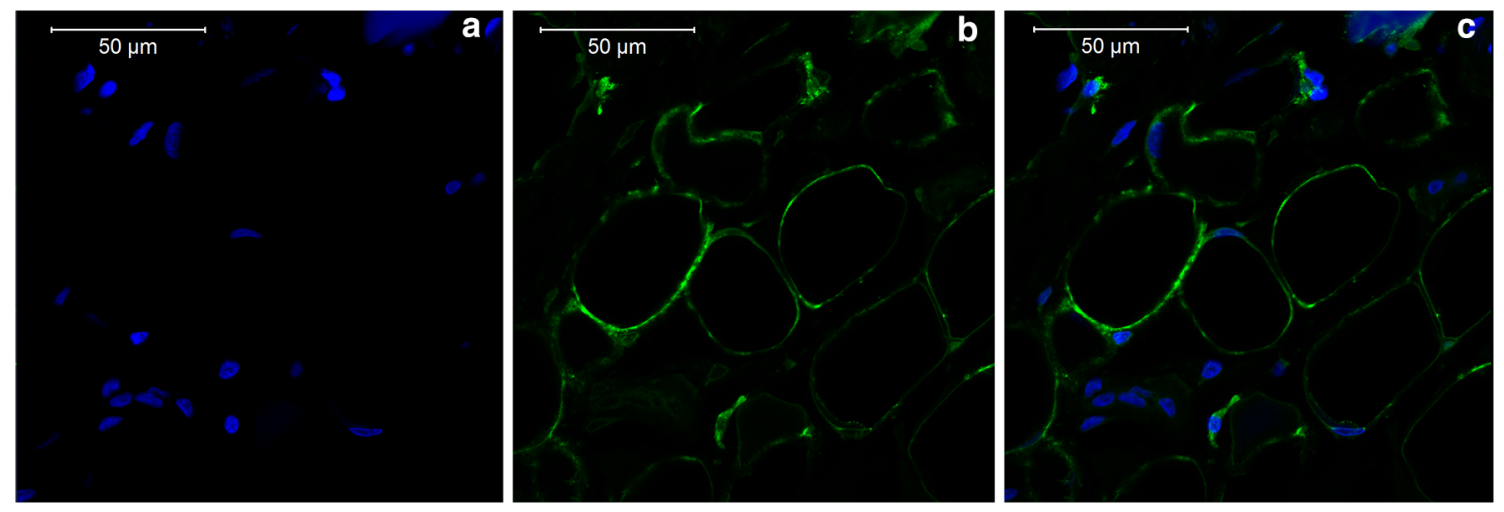

Fig. 14 Expression of CFTR (green) in intra-dermal adipocytes. a Blue-colored DAPI staining of cell nuclei. b Anti-CFTR immunofluorescence (green). c Merged image of (a, b). Similar to $\mathrm{ENaC}$

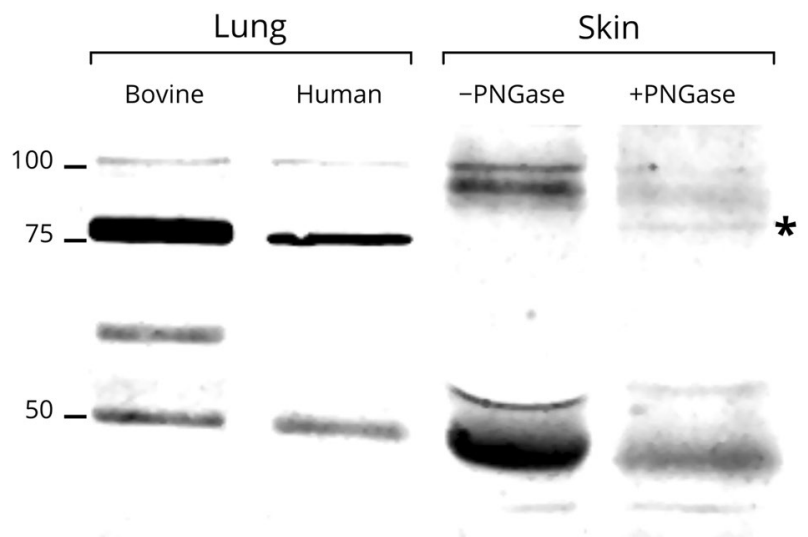

Fig. 15 Western blot of total protein samples from bovine and human lung ( $50 \mu \mathrm{g} / \mathrm{lane})$ and human skin samples, including epidermis and dermis $(200 \mu \mathrm{g} / \mathrm{lane})$. In both the bovine and human lung samples, the major band was at $\sim 75 \mathrm{kDa}$, with additional bands at $\mathrm{Mr}$ values of 50 and 100 . The undigested human skin sample (-PNGase) showed bands at $\sim 50$ and $90-100 \mathrm{kDa}$ range but no detectable band at $\sim 75 \mathrm{kDa}$. In the sample treated with PNGase (+PNGase), the intensity of the $90-100 \mathrm{kDa}$ bands was highly reduced and a new band appeared at $\sim 80 \mathrm{kDa}$ (marked with an asterisk). The blot was reacted with the LI-COR biosystem antibodies, and scanned using LI-COR fluorescence imaging biosystem, as described in "Methods". The background was uniformly reduced across the blot using the LI-COR image studio

experiments wherein we pre-incubated the anti-ENaC antibody with purified rat alpha subunit. The results of these competition experiments showed that the intensity of the bands in the blot that was reacted with the anti-ENaC incubated with purified rat alpha $\mathrm{ENaC}$ was greatly reduced (unpublished).

To examine the possibility that the high MW bands represent glycosylated forms, we carried out two experiments with PNGase F digestion, as described in "Methods". In both experiments, the intensity of the bands in the localization in Fig. 13, CFTR is also localized in a thin cytoplasmic strip in between the cell membrane and the lipid vesicle that fills the adipocyte. Skin sample HSKIF13 from the temple. Scale bars $50 \mu \mathrm{m}$

90-100 kDa range was greatly reduced and a new band appeared at $\sim 80 \mathrm{kDa}$ (Fig. 15). These results confirm that the bands at $\sim 90 \mathrm{kDa}$ represent glycosylated forms of the alpha $\mathrm{ENaC}$ subunit.

\section{Summary of ENaC distribution in skin}

In a previous study, we mapped the sites of localization of $\mathrm{ENaC}$ in the female reproductive tract and the bronchus. In both these tissues, $\mathrm{ENaC}$ was found to be localized to the cell membrane in non-ciliated epithelial cells and on the cilia surface in multi-ciliated cells (Enuka et al. 2012). In skin, $\mathrm{ENaC}$ was localized specifically to the apical cell membrane only in the eccrine sweat glands (Figs. 8, 9). This localization matches the expected function of $\mathrm{ENaC}$ as the channel that reabsorbs $\mathrm{Na}^{+}$from sweat excretions.

In contrast to eccrine glands, in the epidermal layers and the epidermal appendages, including sebaceous glands, smooth muscle cells of arrector pili, and intra-dermal adipocytes, ENaC was localized to the cytoplasm. Since the cytoplasm is adjacent to the cell membrane, the microscopic resolution does not permit distinction between cytoplasmic and membrane localization.

In adipocytes and smooth muscle cells, $\mathrm{ENaC}$ and F-actin filaments appear co-localized (Figs. 11, 13). A recent article has reviewed the previous studies suggesting direct and indirect interactions between $\mathrm{ENaC}$ and actin cytoskeleton (Sasaki et al. 2014).

\section{Skin manifestations in multi-system pseudohypoaldosteronism patients}

In view of the widespread expression of $\mathrm{ENaC}$ in epidermal layers, we reviewed the clinical records of five patients with multi-system PHA who carry mutated $\mathrm{ENaC}$ genes and who have been under our care up to 30 years (see 
"Materials and methods"). As we reported in the past, all patients suffer from impaired salt reabsorption in skin resulting in salt loss via sweat secretions (Hanukoglu 1991; Hanukoglu et al. 1994; Chang et al. 1996; Edelheit et al. 2005). Salt losing aggravates during hot summer days and/ or when ambient temperatures are high. Most of the cases exhibit chronic rhinorrhea as a result increased airway fluid secretion and they have increased salivary sodium concentrations (Kerem et al. 1999). All our patients have long standing skin irritation of various degrees around perioral and perinasal regions due to chronic rhinorrhea and salty salivary secretions (Fig. 16) (Table 2).

Some patients develop folliculitis, pustular, and atopic dermatitis-like skin lesions, over different body regions (Fig. 16). Beside such localized skin lesions that eventually ameliorate with age, we have not observed widespread skin abnormalities in our PHA patients during the course of up to 30 years of clinical follow-up (three of our oldest patients are 27-30 years). Skin manifestations in these patients are summarized in Table 2. None of our patients have suffered from delayed wound healing.

In the literature, there are several case reports on infants with clinical and endocrine features of autosomal recessive PHA (but without identification of a molecular defect in $\mathrm{ENaC}$ genes) that reported erythematous nonfollicular pustules and papules, and miliaria rubra during the first months of life especially when the patient had severe salt wasting crises with marked hyponatremia and hyperkalemia (Aberer et al. 1987; Urbatsch and Paller 2002; Martín et al. 2005; Korkut et al. 2015). The localized skin lesions could be attributable to sweat gland duct occlusion and inflammation of eccrine glands as a result of salt accumulation-in the absence of salt reabsorption. In a skin biopsy of the leg performed in another young baby who suffered from erythematous papules affecting mainly her trunk and limbs (especially during salt wasting episodes), histologic findings were also consistent with this view (Martín et al. 2005).

\section{Functional differences between mouse $\mathrm{ENaC}$ gene knockout models and human PHA}

The multi-system PHA in humans is actually a gene knockout phenotype that results from mutations in $\mathrm{ENaC}$ genes (Chang et al. 1996; Hanukoglu et al. 2008; Hanukoglu and Hanukoglu 2016). To duplicate this syndrome, Hummler et al. generated mouse models with knockout of genes encoding for ENaC subunits (Frateschi et al. 2010). The skin phenotypes of mice without a functional $\alpha-\mathrm{ENaC}$ gene are very severe and include epidermal thickening, changes in epidermal lipid composition, and impaired barrier function (Frateschi et al. 2010). As noted above, in great contrast to the mouse phenotypes, the human PHA cases with $\mathrm{ENaC}$ gene mutations do not result in problems of epidermal differentiation and function other than impaired salt reabsorption.

These major differences raise the question of what is responsible for the difference between the mouse and human phenotypes of ENaC gene dysfunction? One simple possibility is that in humans, $\mathrm{ENaC}$ does not fulfill a major role in epidermal differentiation as it does in mice. This possibility is difficult to accept because of the widespread localization of $\mathrm{ENaC}$ in the epidermal layers.

Before raising an alternative hypothesis for the human vs. mouse phenotypes, we should note a major difference between the human and mouse $\mathrm{ENaC}$ genes. In a survey of the phylogeny of $\mathrm{ENaC}$ genes, it has been noted that the genes coding for all four $\mathrm{ENaC}$ subunits, SCNN1A, SCNN1B, SCNN1G, and SCNN1D, are present in all mammalian genomes examined with the exception of the muridae family of rodents, including Mus musculus, wherein the gene for the delta subunit apparently has been lost (Giraldez et al. 2012; Hanukoglu and Hanukoglu 2016).

The tissue distribution of $\delta$ - $\mathrm{ENaC}$ is different from that of other ENaC subunits (Waldmann et al. 1995; Giraldez et al. 2012; Hanukoglu and Hanukoglu 2016). The $\delta$
Fig. 16 Skin manifestations in multi-system pseudohypoaldosteronism type I patients. Left side Skin manifestations over facial, perioral, perinasal, palpebral regions, and the neck of a patient at the age of $2 / 12$ years (DA in Table 2). Right side Folliculitis over the right thigh of a patient (HS in Table 2) at the age of 14.5 years. Note that there was no skin eruption on the left thigh that is only partially visible
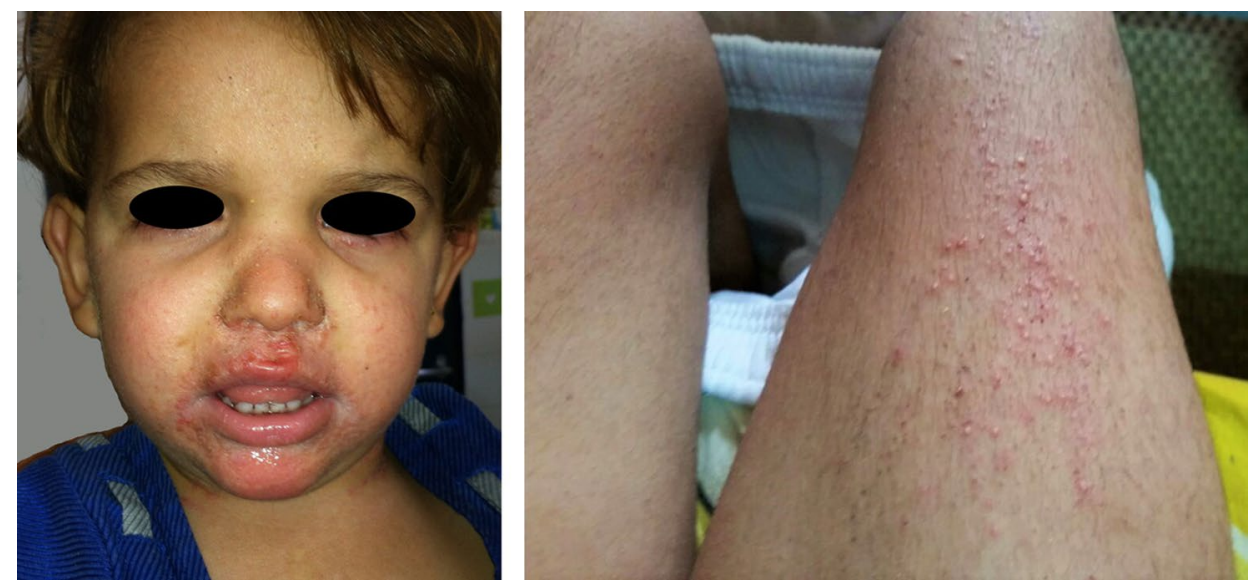
subunit can form a functional channel with the beta and gamma $\mathrm{ENaC}$ subunits in the absence of the alpha subunit (Waldmann et al. 1995). The $\delta$-ENaC is also expressed in the human epidermis and in keratinocytes (Yamamura et al. 2008a). Based on these characteristics of the $\delta$-ENaC and the differences noted above, we raise the hypothesis that in PHA, the absence of one functional ENaC gene (most commonly the alpha subunit is mutated) (Edelheit et al. 2005) may be compensated for by the presence of $\delta$-ENaC. If this hypothesis is true, it can explain why $\mathrm{ENaC}$ gene knockout mice have very severe skin phenotypes as they have no $\delta$-ENaC that can compensate for the dysfunctional $\mathrm{ENaC}$ gene. If this hypothesis is true for epidermal cells, apparently, it does not apply to eccrine glands, because PHA cases suffer from impaired salt absorption as noted above.

\section{The function of the cytoplasmic stores of $\mathrm{ENaC}$ in epidermal cells and interactions with other sodium channels}

Recent studies have provided evidence that $\mathrm{ENaC}$ located in keratinocytes is involved in regulating the sodium homeostasis and the hydration status in skin and its activity influences the extent of fibrosis in skin wounds (Xu et al. 2015a, b). The widespread localization of ENaC subunits in the cytoplasm raises questions about the function and mechanism of activation of these subunits within the epidermal cells. One possibility is that the $\mathrm{ENaC}$ subunits in the cytoplasm serve as stores that could be mobilized to be transferred to the membrane in case of a damage to the epidermis. It has been well established that $\mathrm{ENaC}$ activity can be enhanced by specific proteolytic cleavage of ENaC subunits (Kleyman et al. 2009; Rossier and Stutts 2009). Xu et al. have advanced the hypothesis that a voltage-dependent sodium channel Nax upregulates a membrane-bound serine protease prostasin which in turn activates $\mathrm{ENaC}$ in keratinocytes (Xu et al. 2015b). In addition to these two sodium channels, the epidermis also expresses an $\mathrm{Na}^{+} / \mathrm{H}^{+}$ exchanger 1 (NHE1) (Li et al. 2014). Using amiloride as a high affinity inhibitor of $\mathrm{ENaC}$, and other lines of evidence, $\mathrm{Xu}$ et al. concluded that $\mathrm{ENaC}$ is primarily responsible for the sodium homeostasis in their experimental system (Xu et al. 2015b). Yet, there is still a big gap in our understanding of the molecular events that lead from the cytoplasmic stores of $\mathrm{ENaC}$ to active channels on keratinocyte surface. In view of the large stores of $\mathrm{ENaC}$ subunits, we also should not ignore the possibility that the $\mathrm{ENaC}$ subunits may have a function within the cytoplasm that is different from their common role as ion channel subunits.

In conclusion, in this study, we have documented widespread expression of $\mathrm{ENaC}$ within the cytoplasm in the epidermal layers and epidermal appendages. Yet, the roles of these channel subunits and their mechanism of activation remain to be deciphered.

Acknowledgements We are grateful to Prof. Yardena TenenbaumRakover for referring a patient to us. This research was funded in part by a grant from the United States-Israel Binational Science Foundation (BSF).

\section{References}

Aberer E, Gebhart W, Mainitz M et al (1987) Sweat glands in pseudohypoaldosteronism. Der Hautarzt; Zeitschrift für Dermatologie, Venerol und verwandte Gebiete 38:484-7

Arnoldi R, Hiltbrunner A, Dugina V et al (2013) Smooth muscle actin isoforms: a tug of war between contraction and compliance. Eur J Cell Biol 92:187-200. doi:10.1016/j.ejcb.2013.06.002

Brouard M, Casado M, Djelidi S et al (1999) Epithelial sodium channel in human epidermal keratinocytes: expression of its subunits and relation to sodium transport and differentiation. J Cell Sci 112:3343-3352

Candi E, Schmidt R, Melino G (2005) The cornified envelope: a model of cell death in the skin. Nat Rev Mol Cell Biol 6:328340. doi:10.1038/nrm1619

Canessa CM, Merillat AM, Rossier BC (1994) Membrane topology of the epithelial sodium channel in intact cells. Am J Physiol 267:C1682-C1690

Chang SS, Grunder S, Hanukoglu A et al (1996) Mutations in subunits of the epithelial sodium channel cause salt wasting with hyperkalaemic acidosis, pseudohypoaldosteronism type 1 . Nat Genet 12:248-253. doi:10.1038/ng0396-248

Chen J, Kleyman TR, Sheng S (2014) Deletion of $\alpha$-subunit exon 11 of the epithelial $\mathrm{Na}^{+}$channel reveals a regulatory module. Am J Physiol Renal Physiol 306:F561-F567. doi:10.1152/ ajprenal.00587.2013

Collins KJ, Foster KG, Hubbard JL (1970) Effect of aldosterone on mammalian eccrine sweat glands. Experientia 26:1313-1314

Cui C-YY, Schlessinger D (2015) Eccrine sweat gland development and sweat secretion. Exp Dermatol 24:644-650. doi:10.1111/ exd.12773

Driskell RR, Jahoda CAB, Chuong C-M et al (2014) Defining dermal adipose tissue. Exp Dermatol 23:629-631. doi:10.1111/ exd. 12450

Duc C, Farman N, Canessa CM et al (1994) Cell-specific expression of epithelial sodium channel alpha, beta, and gamma subunits in aldosterone-responsive epithelia from the rat: localization by in situ hybridization and immunocytochemistry. J Cell Biol 127:1907-1921

Eckert RL, Adhikary G, Balasubramanian S et al (2013) Biochemistry of epidermal stem cells. Biochim Biophys Acta 1830:24272434. doi:10.1016/j.bbagen.2012.07.002

Edelheit O, Hanukoglu I, Gizewska M et al (2005) Novel mutations in epithelial sodium channel $(\mathrm{ENaC})$ subunit genes and phenotypic expression of multisystem pseudohypoaldosteronism. Clin Endocrinol (Oxf) 62:547-553. doi:10.1111/j.1365-2265.2005.02255.x

Enuka Y, Hanukoglu I, Edelheit O et al (2012) Epithelial sodium channels $(\mathrm{ENaC})$ are uniformly distributed on motile cilia in the oviduct and the respiratory airways. Histochem Cell Biol 137:339-353. doi:10.1007/s00418-011-0904-1

Farman N, Maubec E, Poeggeler B et al (2010) The mineralocorticoid receptor as a novel player in skin biology: beyond the renal horizon? Exp Dermatol 19:100-107. doi:10.1111/j.1600-0625.2009.01011.x 
Frateschi S, Charles R-P, Hummler E (2010) The epithelial sodium channel $\mathrm{ENaC}$ and its regulators in the epidermal permeability barrier function. Open Dermatol J 4:27-35

Fuchs E, Nowak JA (2008) Building epithelial tissues from skin stem cells. Cold Spring Harb Symp Quant Biol 73:333-350. doi:10.1101/sqb.2008.73.032

Giraldez T, Rojas P, Jou J, et al (2012) The epithelial sodium channel $\delta$-subunit: new notes for an old song. Am J Physiol Renal Physiol 303:F328-F338. doi:10.1152/ajprenal.00116.2012

Hanukoglu A (1991) Type I pseudohypoaldosteronism includes two clinically and genetically distinct entities with either renal or multiple target organ defects. J Clin Endocrinol Metab 73:936-944. doi:10.1210/jcem-73-5-936

Hanukoglu I (2017) ASIC and ENaC type sodium channels: conformational states and the structures of the ion selectivity filters. FEBS J. doi:10.1111/febs.13840

Hanukoglu I, Hanukoglu A (2016) Epithelial sodium channel $(\mathrm{ENaC})$ family: phylogeny, structure-function, tissue distribution, and associated inherited diseases. Gene 579:95-132. doi:10.1016/j.gene.2015.12.061

Hanukoglu I, Tanese N, Fuchs E (1983) Complementary DNA sequence of a human cytoplasmic actin. Interspecies divergence of $3^{\prime}$ non-coding regions. J Mol Biol 163:673-678. doi:10.1016/0022-2836(83)90117-1

Hanukoglu A, Bistritzer T, Rakover Y, Mandelberg A (1994) Pseudohypoaldosteronism with increased sweat and saliva electrolyte values and frequent lower respiratory tract infections mimicking cystic fibrosis. J Pediatr 125:752-755. doi:10.1016/ S0022-3476(06)80176-9

Hanukoglu A, Edelheit O, Shriki Y et al (2008) Renin-aldosterone response, urinary $\mathrm{Na} / \mathrm{K}$ ratio and growth in pseudohypoaldosteronism patients with mutations in epithelial sodium channel (ENaC) subunit genes. J Steroid Biochem Mol Biol 111:268274. doi:10.1016/j.jsbmb.2008.06.013

Hulpiau P, van Roy F (2009) Molecular evolution of the cadherin superfamily. Int J Biochem Cell Biol 41:349-369. doi:10.1016/j.biocel.2008.09.027

Kanzaki M, Pessin JE (2001) Insulin-stimulated GLUT4 translocation in adipocytes is dependent upon cortical actin remodeling. J Biol Chem 276:42436-42444. doi:10.1074/jbc.M108297200

Kenouch S, Lombes M, Delahaye F et al (1994) Human skin as target for aldosterone: coexpression of mineralocorticoid receptors and 11 beta-hydroxysteroid dehydrogenase. J Clin Endocrinol Metab 79:1334-1341. doi:10.1210/jcem.79.5.7962326

Kerem E, Bistritzer T, Hanukoglu A et al (1999) Pulmonary epithelial sodium-channel dysfunction and excess airway liquid in pseudohypoaldosteronism. N Engl J Med 341:156-162. doi:10.1056/NEJM199907153410304

Kleyman TR, Carattino MD, Hughey RP (2009) ENaC at the cutting edge: regulation of epithelial sodium channels by proteases. J Biol Chem 284:20447-20451

Korkut S, Gökalp E, Özdemir A et al (2015) Dermal and ophthalmic findings in pseudohypoaldosteronism. J Clin Res Pediatr Endocrinol 7:155-158. doi:10.4274/jcrpe.1740

Kruglikov IL, Scherer PE, Spalding KL et al (2016) Dermal adipocytes: from irrelevance to metabolic targets? Trends Endocrinol Metab 27:1-10. doi:10.1016/j.tem.2015.11.002

Lehman W, Morgan KG (2012) Structure and dynamics of the actin-based smooth muscle contractile and cytoskeletal apparatus. J Muscle Res Cell Motil 33:461-469. doi:10.1007/ s10974-012-9283-Z

Li H, Zhang X, Zeng S et al (2014) The cellular localization of $\mathrm{Na}(+) / \mathrm{H}(+)$ exchanger 1 , cystic fibrosis transmembrane conductance regulator, potassium channel, epithelial sodium channel $\gamma$ and vacuolar-type $\mathrm{H}^{+}$-ATPase in human eccrine sweat glands. Acta Histochem 116:1237-1243. doi:10.1016/j. acthis.2014.07.005

Martín JM, Calduch L, Monteagudo C et al (2005) Clinico-pathological analysis of the cutaneous lesions of a patient with type I pseudohypoaldosteronism. J Eur Acad Dermatol Venereol 19:377-379. doi:10.1111/j.1468-3083.2004.01173.x

Martinez-Santibañez G, Cho KW, Lumeng CN (2014) Imaging white adipose tissue with confocal microscopy. In: Methods enzymol. pp 17-30

Mauro T, Guitard M, Behne M et al (2002) The ENaC channel is required for normal epidermal differentiation. J Invest Dermatol 118:589-594. doi:10.1046/j.1523-1747.2002.01721.x

Mori S, Kiuchi S, Ouchi A et al (2014) Characteristic expression of extracellular matrix in subcutaneous adipose tissue development and adipogenesis; comparison with visceral adipose tissue. Int J Biol Sci 10:825-833. doi:10.7150/ijbs.8672

Oda Y, Imanzahrai A, Kwong A et al (1999) Epithelial sodium channels are upregulated during epidermal differentiation. J Invest Dermatol 113:796-801. doi:10.1046/j.1523-1747.1999.00742.x

Reddy MM, Light MJ, Quinton PM (1999) Activation of the epithelial $\mathrm{Na}^{+}$channel $(\mathrm{ENaC})$ requires $\mathrm{CFTR} \mathrm{Cl}^{-}$channel function. Nature 402:301-304. doi:10.1038/46297

Rossier BC, Stutts MJ (2009) Activation of the epithelial sodium channel $(\mathrm{ENaC})$ by serine proteases. Annu Rev Physiol 71:361-379

Rossier BC, Baker ME, Studer RA (2015) Epithelial sodium transport and its control by aldosterone: the story of our internal environment revisited. Physiol Rev 95:297-340. doi:10.1152/ physrev.00011.2014

Roudier-Pujol C, Rochat A, Escoubet B et al (1996) Differential expression of epithelial sodium channel subunit mRNAs in rat skin. J Cell Sci 109:379-385

Samuelov L, Sprecher E, Paus R (2015) The role of P-cadherin in skin biology and skin pathology: lessons from the hair follicle. Cell Tissue Res 360:761-771. doi:10.1007/s00441-015-2114-y

Sasaki S, Yui N, Noda Y (2014) Actin directly interacts with different membrane channel proteins and influences channel activities: AQP2 as a model. Biochim Biophys Acta 1838:514-520. doi:10.1016/j.bbamem.2013.06.004

Sato K, Kang WH, Saga K, Sato KT (1989) Biology of sweat glands and their disorders. I. Normal sweat gland function. J Am Acad Dermatol 20:537-563. doi:10.1016/S0190-9622(89)70063-3

Schneider MR, Schmidt-Ullrich R, Paus R et al (2009) The hair follicle as a dynamic miniorgan. Curr Biol 19:R132-R142. doi:10.1016/j.cub.2008.12.005

Shibasaki M, Crandall CG (2010) Mechanisms and controllers of eccrine sweating in humans. Front Biosci (Schol Ed) 2:685-696

Smith KR, Thiboutot DM (2008) Thematic review series: skin lipids. Sebaceous gland lipids: friend or foe? J Lipid Res 49:271-281. doi:10.1194/jlr.R700015-JLR200

Snyder PM, McDonald FJ, Stokes JB, Welsh MJ (1994) Membrane topology of the amiloride-sensitive epithelial sodium channel. J Biol Chem 269:24379-24383

Strautnieks SS, Thompson RJ, Hanukoglu A et al (1996) Localisation of pseudohypoaldosteronism genes to chromosome $16 \mathrm{p} 12.2$ 13.11 and 12p13.1-pter by homozygosity mapping. Hum Mol Genet 5:293-299. doi:10.1093/hmg/5.2.293

Takeichi M (2014) Dynamic contacts: rearranging adherens junctions to drive epithelial remodelling. Nat Rev Mol Cell Biol 15:397410. doi: $10.1038 / \mathrm{nrm} 3802$

Torkamani N, Rufaut NW, Jones L, Sinclair RD (2014) Beyond goosebumps: does the arrector pili muscle have a role in hair loss? Int J Trichol 6:88-94. doi:10.4103/0974-7753.139077

Urbatsch A, Paller AS (2002) Pustular miliaria rubra: A specific cutaneous finding of type I pseudohypoaldosteronism. Pediatr Dermatol 19:317-319. doi:10.1046/j.1525-1470.2002.00090.x 
Waldmann R, Champigny G, Bassilana F et al (1995) Molecular cloning and functional expression of a novel amiloride-sensitive $\mathrm{Na}^{+}$ channel. J Biol Chem 270:27411-27414

Waters JM, Richardson GD, Jahoda CAB (2007) Hair follicle stem cells. Semin Cell Dev Biol 18:245-254. doi:10.1016/j. semcdb.2007.02.003

Wronska A, Kmiec Z (2012) Structural and biochemical characteristics of various white adipose tissue depots. Acta Physiol (Oxf) 205:194-208. doi:10.1111/j.1748-1716.2012.02409.x

$\mathrm{Xu}$ W, Hong SJ, Zeitchek $\mathrm{M}$ et al (2015a) Hydration status regulates sodium flux and inflammatory pathways through epithelial sodium channel $(\mathrm{ENaC})$ in the skin. J Invest Dermatol 135:796806. doi:10.1038/jid.2014.477

$\mathrm{Xu}$ W, Hong SJ, Zhong A et al (2015b) Sodium channel Nax is a regulator in epithelial sodium homeostasis. Sci Transl Med 7:312ra177. doi:10.1126/scitranslmed.aad0286
Yamamura H, Ugawa S, Ueda $\mathrm{T}$ et al (2008a) Epithelial $\mathrm{Na}^{+}$channel delta subunit mediates acid-induced ATP release in the human skin. Biochem Biophys Res Commun 373:155-158. doi:10.1016/j.bbrc.2008.06.008

Yamamura H, Ugawa S, Ueda T, Shimada S (2008b) Expression analysis of the epithelial $\mathrm{Na}^{+}$channel delta subunit in human melanoma G-361 cells. Biochem Biophys Res Commun 366:489_ 492. doi:10.1016/j.bbrc.2007.11.177

Yang H-Y, Charles R-P, Hummler E et al (2013) The epithelial sodium channel mediates the directionality of galvanotaxis in human keratinocytes. J Cell Sci 126:1942-1951. doi:10.1242/ jcs. 113225 